Indonesian Journal of Nutrition and Dietetics Vol. 6, No. 3, 2018: 133-138
Available online at: http://ejournal.almaata.ac.id/index.php/IJND DOI : http://dx.doi.org/10.21927/ijnd.2018.6(3).133-138

\title{
The effect of papaya leaf extract (Carica papaya I.) To the bleeding time on mice with trombositopenia
}

\author{
Saktya Yudha Ardhi Utama ${ }^{1}$ \\ ${ }^{1}$ Department of Nursing, Faculty of Health Science, Universitas Alma Ata, Jalan Brawijaya No 99, Tamantirto \\ Yogyakarta, Indonesia 55183
}

\begin{abstract}
ABSTRAK
Latar belakang: Trombositopenia merupakan suatu keadaan jumlah trombosit di bawah 150.000/mm hal ini dapat menyebabkan perdarahan yang apabila tidak ditangani dengan baik dapat berujung pada kematian. Beberapa tindakan yang dapat dilakukan untuk mengatasi trombositopenia, salah satunya adalah dengan tanaman daun pepaya.

Tujuan: untuk menganalisis pengaruh pemberian ekstrak daun pepaya terhadap bleeding time (waktu perdarahan).

Metode : Desain penelitian ini menggunakan true experimental dengan rancangan post test only control group design. Sampel dalam penelitian ini sejumlah 30 ekor mencit jantan (Mus musculus) yang dibagi menjadi lima kelompok. Kelompok pertama sebagai kelompok kontrol negatif (CMC Na 0,5\%), kelompok kedua sebagai kontrol positif (CMC Na 0,5\%), kelompok ketiga diberi esktrak etanol 96\% daun pepaya dosis 0,5g/kgBB, kelompok keempat diberi esktrak etanol $96 \%$ daun pepaya dosis $1 \mathrm{~g} / \mathrm{kgBB}$, kelompok kelima diberi esktrak etanol $96 \%$ daun pepaya dosis $2 \mathrm{~g} / \mathrm{kgBB}$. Pengumpulan data menggunakan lembar pengukuran bleeding time, yang dianalisa dengan uji ANOVA.

Hasil: Hasil penelitian ini menunjukkan bahwa didapatkan nilai $p<0.0001$ dengan rerata waktu paling cepat antara kelompok perlakuan yaitu kelompok perlakuan dengan dosis $2 g / k g B B(2.74 \pm 0.14)$. Hal ini menunjukkan bahwa terdapat perbedaan signifikan antar semua kelompok.

Kesimpulan: Kesimpulan dari penelitian ini adalah pemberian ekstrak daun pepaya (Carica papaya L.) dapat mempercepat bleeding time (waktu perdarahan).
\end{abstract}

Kata kunci: daun pepaya; bleeding time, trombositopenia

\begin{abstract}
Background: Thrombocytopenia is a condition of platelet counts below $150,000 / \mathrm{mm}^{3}$, this may cause bleeding which, if not handled properly, may lead to death. Some actions that can be done to overcome thrombocytopenia, one of which is with papaya leaf.

Objectives: This study aims to analyze the effect of giving papaya leaf extract to bleeding time.

Methods: This research design uses true experimental with design of post-test only control group design. The sample in this study were 30 male mice (Mus musculus) divided into five groups. The first group as the negative control group ( $\mathrm{CMC} \mathrm{Na} 0.5 \%$ ), the second group as the positive control (CMC Na $0.5 \%$ ), the third group was given ethanol $96 \%$ extract papaya leaf dose $0.5 \mathrm{~g} / \mathrm{kgBW}$, the fourth group was given ethanol $96 \%$ extract papaya leaf dose $1 \mathrm{~g} / \mathrm{kgBW}$, the fifth group was given ethanol $96 \%$ extract papaya leaf dose $2 \mathrm{~g} / \mathrm{kgBW}$. Data collection using measurement sheet of bleeding time which were analyzed by ANOVA test.

Results: The results of this study showed that $p<0.0001$ the fastest mean time occur between treatment groups that is treatment group with dose $2 \mathrm{~g} / \mathrm{kgBW}(2.74 \pm 0.14)$. In the bleeding time variables $p<0.0001$ the fastest mean time occur between treatment groups that is treatment group with dose $2 \mathrm{~g} / \mathrm{kgBW}(2.74 \pm 0.14)$. This result shows that there are significant differences between every groups.

Conclusion: The conclusion of this research is giving papaya leaf extract can increase bleeding time.
\end{abstract}

Keywords: leaf of papaya, bleeding time, thrombocytopenia. 


\section{INTRODUCTION}

Platelets are blood cells that an important role in the process of stopping bleeding from a damaged blood vessel (1). In the condition of thrombocytopenia, there is an increased risk of bleeding which if not handled properly will worsen the patient's condition and cause death. One disease that is characterized by bleeding is dengue hemmoraghic fever which has become a serious disease in Indonesia, but until now there has not been found a drug or vaccine that can cure the disease, as well as the lack of alternative drugs to increase platelet counts (2).

One of the plants that is often used in the community to treat dengue hemmoraghic fever (DHF) is the papaya plant. In the Pekanbaru area, some people use papaya by taking a papaya leaf and boiling the leaves taken before going to bed as therapy for DHF patients. The Javanese and Manado people also use papaya leaves as a medicinal plant to treat DHF disease (3).

Data from the Ministry of Health states that as many as 511 districts / cities in Indonesia have the potential to become places for developing DHF (4). In early 2016, the East Java Provincial Government noted that there were 2,027 cases of dengue fever in 38 districts / cities, 40 of whom died. The death toll reached 40 people. A number of regions also experienced more than double the number of cases compared to the same month in 2015 , namely Sidoarjo and Kota Probolinggo. Sidoarjo in January 2015 there were 21 cases and 2016 with 45 cases. Meanwhile, the city of Probolinggo in January 2015 amounted to 20 cases and 2016 with 47 cases (5).

Thrombocytopenia is a state of platelet count below $150,000 / \mathrm{mm} 3$, this can inhibit blood clotting and may even cause fatal bleeding. Thrombocytopenia is a hematological disorder characterized by a decrease in platelet levels in the blood which can also be caused by various factors such as drug induction such as cancer chemotherapy, heparin, quinidine, quinine, gold salts, valproic acid, sirolimus and sulfa antibiotics (6). The normal hemostatic mechanism of the body is sufficient to repair damage and stop the release of blood from these fine microcirculation vessels. The mechanism of the body in stopping bleeding involves three main steps: vascular spasm, platelet blockage formation, and blood coagulation (7). If there is a wound in a blood vessel, vasoconstriction of the blood vessels will occur immediately so that blood flow to the injured blood vessels decreases. Then the platelets will gather and attach to the part of the injured blood vessel to form a platelet plug. Activated blood clotting factors will form fibrin threads that will form a platelet plug to become non-permeable so that bleeding will stop. There are several systems that play a role in hemostasis, namely the vascular system, platelets and blood clots (8).

Handling that can be done to overcome this bleeding problem is by Thrombocyte Concentrate (TC) transfusion, both as a therapy and prophylactic action in thrombocytopenia patients with the risk of bleeding. (9). TC transfusion can cause various side effects. Some of the side effects that can arise due to the presence of leukocyte contaminants in this TC component include: non-hemoglobin transfusion reactions (FNHTR), transfusion related lung injury (TRALI), alloimmunization, increased risk of viral transmission (especially cytomegalovirus) and so on. (10).

In the case of a decrease in platelet counts, for example in DHF, medicinal plants that are often used to increase platelets include sweet potatoes, guava extracts, dates and black cumin extracts (11). In addition to these plants there is an alternative plant that is easily found, one of which is papaya (Carica papaya Linn) which is thought to affect platelet activity. In Patil's research (2013), papaya leaf extract was shown to be able to increase platelet counts but its effect on bleeding time is unknown. Papaya leaves are also able to treat Dengue Hemmoraghic Fever (DHF) sufferers who have thrombocytopenia. Papaya plants are tropical plants that thrive in Indonesia, making them easy to obtain and the price is more economical. Papaya leaves contain several secondary metabolites, one of which is flavonoids and tannins (12). Based on research conducted by Soegijanto, et al (2010), total flavonoid compounds and total tannin are marker compounds in increasing blood platelet counts in DHF patients. In addition, papaya leaves also 
contain alkaloids including carpain, pseudocarpain and dehydrocarpain I and II which can react to the bone marrow to prevent their destruction and increase platelet production (13).

\section{MATERIALS AND METHODS}

This study uses true experimental design with a post test only control group design. This research was conducted in February-March 2017. This research has been submitted to the Research Ethics Commission of the Faculty of Veterinary Medicine, Airlangga University number 662-KE by applying the principle of $3 R$ (Replacement, Reduction, Refinement) and has been declared ethical. The tools and materials in this study are polypropylene plastic cages for mice measuring $20 \mathrm{~cm} \times 30 \mathrm{~cm}$ $x 40 \mathrm{~cm}$ which are covered with wire mesh with a hole size of $6 \mathrm{~mm}$, drinking bottles, places to eat, husks, scales, sonde, syringes $1 \mathrm{ml}$, sterile tubes, blood analyzer, stopwatch, absorbent paper, scalpel, syringe, serotonin ELISA kit, Elisa reader, Elisa washer, well plate, micropipette, ultrasonic device, vacuum rotary evaporator, oven and petri dish.

This study used mice (Mus musculus) as experimental animals with criteria for male sex, age 3 months, body weight 25-30 grams and healthy conditions. The samples in this study were 30 mice (Mus musculus) which were divided into five groups. Each group consists of 6 mice. The first group was the negative control group (CMC Na $0.5 \%$ ), the second group was positive control (CMC Na $0.5 \%$ ) , the third group was given ethanol extract $96 \%$ papaya leaf dose $0.5 \mathrm{~g} / \mathrm{kgBB}$, the fourth group was given extract ethanol 96\% papaya leaves dose $1 \mathrm{~g} /$ $\mathrm{kgBB}$, the fifth group was given $96 \%$ ethanol extract of papaya leaves dose of $2 \mathrm{~g} / \mathrm{kgBW}$. Mice were made thrombocytopenia by inducing cotrimoxazole at a dose of $249.6 \mathrm{mg} / \mathrm{kgBB}$ (p.o) for 8 days.

Papaya leaves are selected which are still fresh, washed, cut and dried by aerating, then pollinated using a blender. As much as 200 grams of simplisa papaya powder are added with $96 \%$ ethanol and to accelerate the extraction process ultrasonic devices are used. This ultrasonic treatment is repeated for 3 times, each treatment takes 2 minutes. The ultrasonic results of each treatment were filtered using a filter and filter paper which was then stored in a bottle for evaporation for 12 hours. To get a thick extract, then the solution of plant leaves that have been through evaporation is put in an oven / heater with a temperature of 39-40 $\mathrm{C}$ for 3 days. After the thick extract is obtained, then measure the yield.

Papaya leaf extract according to the dosage of each treatment group was put into the test tube dissolved in $\mathrm{CMC} \mathrm{Na} 0.5 \%$ until the volume was exactly $10 \mathrm{ml}$, stirred until homogeneous. $0.5 \mathrm{ml}$ taken with $1 \mathrm{ml}$ syringe to be given to each test animal. Given $96 \%$ ethanol extract of papaya leaves every day for 5 days, then bleeding time was examined in all groups.

Mice that have fulfilled the criteria are given injuries by means of the mouse mice being marked 2 $\mathrm{cm}$ long from the tip of the tail. The hair on the tail is cleaned using a hair shaver then cleaned using $70 \%$ ethanol, anesthetized topically using ethyl chloride around the tail to be injured, then given a $3 \mathrm{~mm}$ wound using a minor surgery. The outgoing blood is absorbed using filter paper every 30 seconds without touching the wound surface. Time begins to be measured using a stop watch when the blood is absorbed for the first time until the blood stops with no blood being absorbed on the filter paper. The time interval when the blood comes out first until the blood stops coming out is the bleeding time.

Data collection uses a bleeding time measurement sheet. Data processing and analysis by using SPSS and One Sample Kolmogorov Smirnov normality test $(p>0.05)$ followed by Anova test. Data that has been processed and analyzed is presented in table form.

\section{RESULTS}

Table 1 shows that the longest average bleeding time was negative control group, ie the group of normal mice without treatment was 3.64 \pm 0.18 while the fastest bleeding time was found in the treatment group with papaya leaf extract dose of $2 \mathrm{~g} / \mathrm{kgBB}$ which is $2.74 \pm 0.14$. The difference in bleeding time values between the control group and 
Table 1 Mean Value and Standard Deviation of Variable Bleeding Time (minutes).

\begin{tabular}{cc}
\hline Group & Mean \pm SD \\
\hline negative control & $2.76^{\mathrm{a}} \pm 0.22$ \\
positive control & $3.64^{\mathrm{b}} \pm 0.18$ \\
extract dose $0,5 \mathrm{~g} / \mathrm{kgBB}$ & $3.13^{\mathrm{c}} \pm 0.15$ \\
extract dose $1 \mathrm{~g} / \mathrm{kgBB}$ & $2.95^{\mathrm{a}, \mathrm{c}} \pm 0.14$ \\
extract dose $2 \mathrm{~g} / \mathrm{kgBB}$ & $2.74^{\mathrm{a}} \pm 0.14$ \\
ANOVA $p<0.0001$ & \\
\hline
\end{tabular}

* Different letters show significant differences based on the LSD test at $\alpha=0.05$

the treatment group was carried out by the ANOVA test with a $95 \%$ confidence level obtained by $p$-value $=0,000$, which means that at least a pair of groups had a difference in the average bleeding time.

Table 2 Differences in Bleeding Time Values in the Control Group and Treatment

\begin{tabular}{cc}
\hline Group & p-value \\
\hline negative control & \\
positive control & 0.000 \\
extract dose $0,5 \mathrm{~g} / \mathrm{kgBB}$ & \\
extract dose $1 \mathrm{~g} / \mathrm{kgBB}$ & \\
extract dose $2 \mathrm{~g} / \mathrm{kgBB}$ & \\
\hline
\end{tabular}

Based on Table 2, p-value $=0,000$ is obtained so that at least there is a pair of groups that have different mean bleeding time. To find out which groups are different, then proceed with the Post Hoc test using LSD.

From the results of the LSD test, it was found that the bleeding time at negative control group had significant differences with positive control group $(p$ $<0,0001)$ and extract dose $0,5 \mathrm{~g} / \mathrm{kgBB}$ group $(\mathrm{p}=0.001)$ but did not have a significant difference with extract dose $1 \mathrm{~g} / \mathrm{kgBB}$ group $(\mathrm{p}=0,056)$ and extract dose 2 $\mathrm{g} / \mathrm{kgBB}$ group ( $\mathrm{p}=0.826$ ) while positive control group has significant differences with extract dose $0,5 \mathrm{~g} /$ kgBB group, extract dose $1 \mathrm{~g} / \mathrm{kgBB}$ group and extract dose $2 \mathrm{~g} / \mathrm{kgBB}$ group $(p<0.0001)$. extract dose $0,5 \mathrm{~g} /$ $\mathrm{kgBB}$ group has a significant difference with extract dose $2 \mathrm{~g} / \mathrm{kgBB}$ group $(p<0,0001)$ but does not have a significant difference with extract dose $1 \mathrm{~g} / \mathrm{kgBB}$ group $(p=0,087)$ while extract dose $1 \mathrm{~g} / \mathrm{kgBB}$ group has a significant difference with extract dose $2 \mathrm{~g} / \mathrm{kgBB}$ group $(p=0.035)$.

\section{DISCUSSION}

This study aims to see whether there is an effect of giving papaya leaf extract to bleeding time. The results of this study indicate that the treatment group given papaya leaf extract showed a faster bleeding time than the positive thrombocytopenia control group. The treatment group given the papaya leaf extract at a dose of $2 \mathrm{~g} / \mathrm{kgBB}$ showed the fastest bleeding time compared to the other treatment groups with an average of $2.74 \pm 0.14$.

There are several compounds in papaya leaves that function as hemostatic agents. Some of these compounds are flavonoids and tannins. The mechanism of tannin in stopping bleeding is through its astringent effect (14). Flavonoid compounds can stop bleeding with vasoconstriction mechanisms in blood vessels (15). Flavonoids and tannins contained in papaya leaves are thought to play a role in inhibiting local synthesis and production of vasodilatory prostaglandin 12 (prostacyclin) which causes the process of wound contraction (vasoconstriction) to be faster (16). Tanin is one component that is responsible for the secretion of 5-hydroxytryptamin (serotonin) and thromboxane A2 (17).

The flavonoids and tannins they contain are thought to play a role in inhibiting local synthesis and production of vasodilating prostaglandin 12 (prostacyclin) so that the process of wound contraction (vasoconstriction) becomes faster (16). Tanin is one component that is responsible for 5-hydroxytryptamin (serotonin) secretion and thromboxane A2 (17).

Serotonin and thromboxane A2 are compounds secreted due to the response to platelet activation that attaches to the walls of damaged blood vessels. Serotonin functions as a strong vasoconstrictor, while thromboxane $\mathrm{A} 2$ also functions as a vasoconstrictor, contributes to the process of the activation of adjacent platelets and because of the sticky nature of these additional platelets, it will cause it to attach to previously active platelets (platelet aggregation). This platelet activation cycle continues, causing more additional platelet withdrawals to form platelet plugs. This plug 
is initially loose, but usually can successfully block the loss of blood if the wound is in a small blood vessel, but if the wound is large, a blood clotting mechanism is needed to stop bleeding (18).

The results of this study can be explained that the administration of $96 \%$ ethanol extract of papaya leaves at a dose of $2 \mathrm{gr} / \mathrm{kg}$ has an effect on blood cessation up to the same limit as the negative control group (normal). This is because the substances contained in papaya leaf extract are more optimal in stopping bleeding at that dose.

\section{CONCLUSION}

Giving papaya leaf extract (Carica papaya L.) at a dose of $0.5 \mathrm{~g} / \mathrm{kgBB}, 1 \mathrm{~g} / \mathrm{kgBB}$ and $2 \mathrm{~g} / \mathrm{kgBB}$ can accelerate bleeding (bleeding time). Papaya leaf extract at a dose of $2 \mathrm{~g} / \mathrm{kgBB}$ gives the maximum effect in accelerating bleeding time (bleeding time).

\section{REFERENCES}

1. Ahmad N, Fazal H, Ayaz M, Haider B \& Fazal L. 2011. Dengue Fever Treatment with Carica papaya Leaves Extracts. Asian Pacific Journal of Tropical Biomedicine. vol 1. no 4 : 330-333.

2. Winarno, M W, Yesi S \& H. Sediarso. 2009. Efek Daun Dewa (Gynura pseudo-china Aug D.C.) terhadap Peningkatan Trombosit Tikus Putih yang Diinduksi Hidroksi Urea. Jurnal Kefarmasian Indo. vol 1. no 2 : 59-63.

3. Pramono S. 2010. Kontribusi Bahan Obat Alam dalam Mengatasi Krisis Bahan Obat di Indonesia. Jurnal Bahan Alam Indonesia. vol $1: 12-13$.

4. CNN Indonesia. 2016. Kemenkes: Indonesia Belum Bebas Demam Berdarah. http://www.cnnindonesia.com/gayahidup/20160112160559255103778/ kemenkesindonesia-belum-bebas-demam-berdarah/. Diakses pada tanggal 10 Oktober 2016

5. Dinkes Provinsi Jawa Timur. 2016. Profil Kesehatan Provinsi Jawa Timur. http://www. dinkesjatimprov.go.id. Diakses pada tanggal 10 Oktober 2016.
6. Adnyana I K, Sigit J K \& Nurlina. 2012. Pengaruh Pemberian Konsentrat Ikan Gabus (Channa striata) Terhadap Profil Darah Mencit Balb/C Model Trombositopenia. Jurnal Medika Planta. vol 2. no 1 : 13-25.

7. Adnyana IK, Sigit J K \& Nurlina. 2012. Pengaruh Pemberian Konsentrat Ikan Gabus (Channa striata) Terhadap Profil Darah Mencit Balb/C Model Trombositopenia. Jurnal Medika Planta. vol 2. no 1 : 13-25.

8. Setiabudy R.D. 2012. Hematosis Dan Trombosis. Jakarta : Badan Penerbit FKUI

9. Blumberg Neil, Joanna M Heal, Gordon L Phillips \& Richard P Phipps. 2012. Platelets To Transfuse Or Not To Transfuse. The Lancet. vol 380. no $9850: 1287-1289$

10.Gernsheimer T, Richard MK, Benjamin D, Steven Kleinman, Alan T, Kelley E, Mark D. 2015. Platelet Transfusion: A Clinical Practice Guideline From the AABB. Ann Intern Med Journal. vol 162. no $13: 205-213$

11.Djunaedi, D. 2006. Demam Berdarah Epidemilogi, Imunopatologi, Patogenesis, Diagnosis dan Penatalaksanaannya. Malang : UMM Press. Hal : 34-35.

12.Milind, $P$ \& Gurditta. 2011. Basketful Benefits of Papaya. IRJP. vol 2. no $7: 6-12$.

13. Soegijanto S, Azhali MS, Alan R, Anggraini, Rulik R \& Dian D. 2010. Uji Klinik Multisenter Sirup Ekstrak Daun Jambu Biji Pada Penderita Demam Bedarah Dengue. Medicinus. vol 23. no 1 : 5-10. 14. Klatoe JR, Dougnon TV, Sacramento TI, Dandjesso, Edorh AP \& Koudokpon. 2012. Hemostatic Potential of The Sap of Musa sapientum L (Musaceae). Journal of Applied Pharmaceutical Science. vol 2. no 6 : 65-69.

15.Dougnon TV, Tamegnon VD, Jean RK, Julien S \& Jean MA. 2012. In Vitro Hemostatis Activity Screening of Sap of Jatropha Multifide L. (Euphorbiaceae) Used in Traditional Medicine at Cotonoun. Journal of Physiology and Pharmacology Advance. vol 2. no 6 : 227-234. 16.Salawu O.A., Aliyu M., Tijani A.Y. 2008. Haematological Studies on The Ethanolic Stem Bark Extract Of Pterocarpus Erinaceus Poir 
(Fabaceae). African Journal of Biotechnology. vol. 7 (9) :1212-15

17.Sari R.P., Sampurna. \& Danis P. 2013. Pengaruh Sari Buah Kurma (Phoenix dactylifera) terhadap Waktu Perdarahan. Sains Medika. vol. 5. no 1: 20-22
18.Patil S, Supritha S, Rama B \& Shridhar N. 2013. Evaluation of Platelet Augmentation Activity of Carica papaya Leaf Aqueous Extract in Rats. Journal of Pharmacognosy and Phytochemistry. vol 1. no $5: 57-60$. 